nance study of p-benzoquinone polymers incorporating amino nitrogen compounds ("synthetic humic acid"). Soil Sci. 134:277-293.

Rieger, P.-G., and H.-J. Knackmuss. 1995. Basic knowledge and perspectives on biodegradation of 2,4,6-trinitrotoluene and related nitroaromatic compounds in contaminated soil. p. 1-17. In J.C. Spain (ed.) Biodegradation of nitroaromatic compounds. Plenum Press, New York.

Schackmann, A., and R. Müller. 1991. Reduction of nitroaromatic compounds by different Pseudomonas species under aerobic conditions. Appl. Microbiol. Biotechnol. 34:809-813.

Schnitzer, M. 1978. Humic substances: Chemistry and reactions. p. 1-64. In M. Schnitzer and S.U. Khan (ed.) Soil organic matter. Elsevier, Amsterdam.

Schulten, H.-R., and M. Schnitzer. 1998. The chemistry of soil nitrogen: a review. Biol. Fertil. Soils. 26:1-15.

Scott, D.T., D.M. McKnight, E.L. Blunt-Harris, S.E. Kolesar, and D.R. Lovley. 1998. Quinone moieties act as electron acceptors in the reduction of humic substances by humics-reducing microorganisms. Environ. Sci. Technol. 32:2984-2989.

Sheremata, T.W., S. Thiboutot, G. Ampleman, L. Paquet, A. Halasz, and J. Hawari. 1999. Fate of 2,4,6-trinitrotoluene and its metabolites in natural and model soil systems. Environ. Sci. Technol. 33:40024008 .
Suflita, J.M., and J.-M. Bollag. 1981. Polymerization of phenolic compounds by a soil-enzyme complex. Soil Sci. Soc. Am. J. 45:297-302.

Thiele, S., and G.W. Brümmer. 1998. Influence of soil moisture on the remobilization of previously bound $\mathrm{PAH}$ residues in contaminated soils. p. 117-122. In DFG (ed.) Pesticide bound residues in soil. Wiley/VCH, Weinheim, Germany.

Thiele, S., C.J. Wang, and J.-M. Bollag. 1998. Enhanced transformation of nitroaromatic compounds by a fungal laccase in the presence of humic monomers. p. 438. In Abstracts of the 98th Gen. Mtng. Am. Soc. Microbiol., Atlanta, GA, 17-21 May 1998. American Society for Microbiology.

Thorn, K.A. 1997. Covalent binding of the reductive degradation products of TNT to humic substances examined by N-15 NMR. Division of Environmental Chemistry Preprints of Extended Abstracts, 37:305-306.

Thorn, K.A., P.J. Pettigrew, W.S. Goldenberg, and E.J. Weber. 1996. Covalent binding of aniline to humic substances. $2 .{ }^{15} \mathrm{~N}$ NMR studies of nucleophilic addition reactions. Environ. Sci. Technol. 30:27642775.

Vorbeck, C., H. Lenke, P. Fischer, J.C. Spain, and H.-J. Knackmuss. 1998. Initial reductive reactions in aerobic microbial metabolism of 2,4,6-trinitrotoluene. Appl. Environ. Microbiol. 64:246-252.

\title{
Formation of Heteroaromatic Nitrogen after Prolonged Humification of Vascular Plant Remains as Revealed by Nuclear Magnetic Resonance Spectroscopy
}

\author{
H. Knicker,* P. G. Hatcher, and F. J. González-Vila
}

\begin{abstract}
In the search for the mechanisms involved in the immobilization of organic nitrogen in humified remains of vascular plants, the efforts of the present investigation were directed toward the examination of the transformation of nitrogenous compounds during the peat and coal stage by means of solid-state nuclear magnetic resonance (NMR) spectroscopy. While accumulation of heteroaromatic-N is not detected in most of the studied peat layers, a clear shoulder in the chemical shift region of pyrrole- or indole- $N$ is observed in the solid-state ${ }^{15} \mathbf{N}$ NMR spectrum of material from the deepest (and thus oldest) peat layer underlying the sapropel from Mangrove Lake, Bermuda (10 000 years). This points to the assumption that transformation of nitrogen occurs between an advanced stage of peatification and an early stage of coalification. The observed sudden alteration in nitrogen functionality indicates that continuous accumulation of newly synthesized or selectively preserved biogenic structures is not responsible for the presence of heteroaromatic- $\mathrm{N}$ in these fossilized deposits. It seems rather likely that abiotic conditions, occurring during advanced sediment maturation, have an effect on the observed $N$ transformation. With increasing coalification, pyrrole-type- $\mathrm{N}$ becomes the dominant form in the macromolecular coal network. Pyridine-type-N was only detected in a coal of anthracite rank.
\end{abstract}

$\mathrm{T}$ HE IMPORTANCE OF refractory organic nitrogen in soils and sediments as a nitrogen sink is well recognized but little is known concerning its chemical composition or the mechanism(s) responsible for its resistance.

Heike Knicker, Lehrstuhl für Bodenkunde, Technische Universität München, 85350 Freising-Weihenstephan, Germany. P.G. Hatcher, Department of Chemistry, The Ohio State University, Columbus, $\mathrm{OH}$ 43210. F.J. González-Vila, Instituto de Recursos Naturales y Agrobiología, C.S.I.C., P.O. Box 1052, 41080 Sevilla, Spain. Received 26 June 2000. *Corresponding author (knicker@weihenstephan.de).

Published in J. Environ. Qual. 31:444-449 (2002).
Common models that were proposed to explain the formation of refractory organic nitrogen involve the depolymerization-recondensation pathway (Anderson et al., 1989; Kelly and Stevenson, 1996; Schnitzer, 1985). Here, naturally occurring macromolecules such as lignin, polysaccharides, and proteins are microbiologically degraded to oligomers and monomers, which for the most part are mineralized further. A small fraction of these oligomers and monomers, however, are thought to recombine by random condensation or 1,4 addition of ammonium and amino groups on phenols or quinone to form complex macromolecular N-containing heteroaromatic structures. Another suggestion is the formation of Maillard products by condensation of carbonyl- $\mathrm{C}$ with amino groups in amino acids and amino sugars (Ikan, 1996). Several of the suggested pathways have been shown to occur in laboratory experiments. In natural soils, however, up to now, possible end products of such condensation reactions were only detected by pyrolysis (Schulten et al., 1995) and in concentrations that are to low to be considered to be a major building block of soil humic material. Previous solid-state ${ }^{15} \mathrm{~N}$ nuclear magnetic (NMR) spectroscopic studies, on the other hand, revealed that nitrogen in humified material of soils (Knicker et al., 1993, 1999, 2000; Knicker and Lüdemann, 1995) and recent sediments (Knicker and Hatcher, 1997; Knicker et al., 1996c) is mainly bound in amides. Applying thermochemolysis with tetramethylammonium hydroxide to a residue of a 5000-year-old organic sediment obtained after hydrolysis with $6 \mathrm{M}$ $\mathrm{HCl}$ confirmed the presence of nonhydrolyzable amino-

Abbreviations: CPMAS, cross polarization magic angle spinning; NMR, nuclear magnetic resonance. 
acid compounds. This study clearly demonstrated that in humified organic material peptide-like material exists that is resistant against microbial attack but also against harsh chemical treatment, possibly by physical or chemical protection (Knicker et al., 2001). In those studies, no evidence for the formation of higher amounts of heteroaromatic- $\mathrm{N}$ in those environments was obtained. However, such heteroaromatic-N was shown to dominate in solid-state ${ }^{15} \mathrm{~N}$ NMR spectra obtained from bituminous coals (Knicker et al., 1995). A comparable observation was made for algal-derived deposits (Derenne et al., 1997; Knicker et al., 1996c). This observation demonstrates that during fossilization of organic material, significant changes in nitrogen composition occurred leading to $\mathrm{N}$-containing constituents that are not observed for humified material in soils and recent algalderived sediments. In order to obtain some more insights into involved mechanisms responsible for this shift in nitrogen functionality, the timing of the formation of heteroaromatic-N is an important question. According to previous solid-state ${ }^{15} \mathrm{~N}$ NMR studies, it seems unlikely that higher amounts of such compounds are formed during early diagenesis. However, at a later stage of diagenesis the higher resistance of heteroaromatic compounds against degradation as compared with amides may finally account for their selective enrichment. If this is the case, a continuous increase in heteroaromatic-N with simultaneous decrease of amide-N should be observable in a series of samples with increasing diagenetic maturation degree. On the other hand, in the deeper layers of a sediment, continuing diagenesis leads to consolidation of the accumulated material, reduction in water content, and an increase in temperature, due to increase in pressure. Microbial activity decreases and finally stops at a later stage referred to as catagenesis. At this stage, abiotic conditions or thermal transformations could assist in the formation of the observed heteroaromatic-N.

The efforts of the present investigation were directed toward the examination of organic matter transformation during peatification and fossilization of vascular plant debris. Therefore, several peats and coals that increase in rank from lignite to anthracite were subjected to solid-state ${ }^{13} \mathrm{C}$ and ${ }^{15} \mathrm{~N}$ NMR spectroscopy. With this approach, we hoped to map out a more precise time window during which the formation of heteroaromatic-N occurred than was achieved in previous studies on the fossilization of algal material (Derenne et al., 1997). This should improve the possibility to mark down factors that can lead to the immobilization of organic nitrogen into heteroaromatic compounds.

\section{MATERIALS AND METHODS}

\section{Sample Material}

The first peat sample used in this study was derived from Mangrove Lake, Bermuda (Hatcher, 1978; Hatcher et al., 1982) and has developed for more than 10000 years. In this deposit, freshwater peat overlies the carbonate basement. The peat is covered by an algal sapropel. The sharp transition from peat to algal sapropel occurs at $14 \mathrm{~m}$ depth of the sediment. Thin sections and isotopic ${ }^{13} \mathrm{C}$ measurements of the peat indicated that it is composed of remains of sawgrass, ferns, palms, and myrtle (Hatcher et al., 1982).

The second peat sample was Torreblanca peat (sapric peat) (Almendros et al., 1981) from Castellón de Plana, eastern Spain, which is a coastal formation with pallustric vegetation (continental-marine swamps). This sediment is used for fuel and fertilizer production. Samples were taken at a depth of 80 to 100 and 100 to $200 \mathrm{~cm}$. A second sapric peat was obtained at a depth of $200 \mathrm{~cm}$ from the Padul deposit in the Miocene Granada Basin (southern Spain).

Two lignite samples were taken from the Arenas del Rey deposit of the same basin. These samples are from a depth of $1.5 \mathrm{~m}$ and of $3.5 \mathrm{~m}$. The geological background for the Padul deposit and the Arenas del Rey deposits are described in Florschütz et al. (1971) and Martín and Garcia-Rosell (1970), respectively. A brief description of the samples is given by del Río et al. (1992). The highly volatile A bituminous coal PSOC 1362 was derived from the Penn State Coal Sample Bank and Data Base and has been characterized thoroughly by standard chemical methods (Glick and Davis, 1991). This coal (Middle Pennsylvanian) was collected from Tallegheny Group, Freeport Formation (Lawrence County, Pennsylvania, USA). A coalified stem of anthracite rank was obtained from a sandstone unit of the Lockatong Formation (Upper Triassic) at the $\mathrm{H}$ and $\mathrm{K}$ quarry near Chalfont, Pennsylvania, USA (Hatcher, 1988; Hatcher and Ronankiw, 1985).

The elemental composition of the samples included in Table 1 was measured in duplicates by standard elemental analysis at the microanalysis laboratory of the Universität Regensburg, Germany.

\section{Nuclear Magnetic Resonance Measurements}

The solid-state cross polarization magic angle spinning (CPMAS) ${ }^{13} \mathrm{C}$ NMR spectra were obtained with a Bruker (Rheinstetten, Germany) MSL-100 (25.2 MHz) spectrometer, using zirconium rotors of $7 \mathrm{~mm}$ o.d. with KEL-F-caps that were spun at $4 \mathrm{kHz}$, respectively. A standard cross polarization pulse sequence was applied (Pines et al., 1973; Schaefer and Stejskal, 1976). A contact time $t=1 \mathrm{~ms}$ was used for these spectra. The ${ }^{13} \mathrm{C}$ chemical shift was calibrated to tetramethylsi-

Table 1. Elemental composition ( $\mathrm{mg} \mathrm{g}^{-1}$ dry mass of the sample) and intensity distribution (\% of total signal intensity) in the cross polarization magic angle spinning (CPMAS) ${ }^{13} \mathrm{C}$ nuclear magnetic resonance (NMR) spectra of Torreblanca peats (southern Spain) and the deposits of the Miocene Granada Basin, southern Spain.

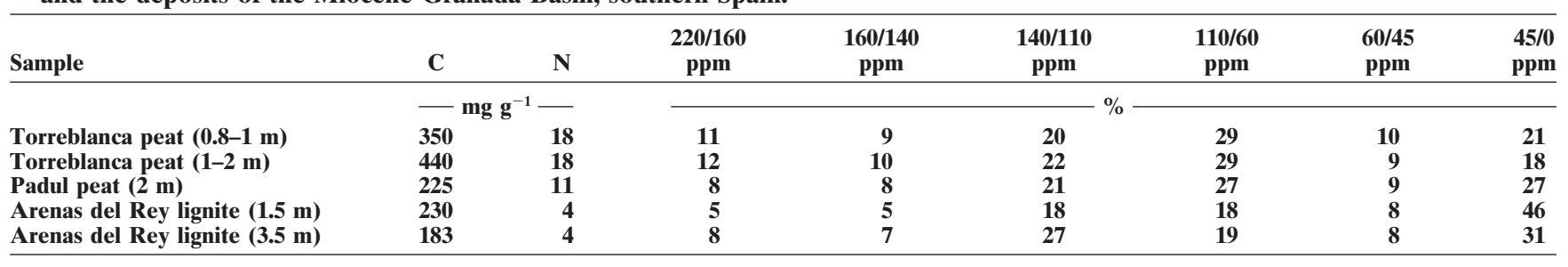


lane $(=0 \mathrm{ppm})$, using glycine as an external standard $(\mathrm{COOH}$ : $176.04 \mathrm{ppm})$. Depending on the sensitivity of the sample for NMR analysis, between $2 \times 10^{4}$ and $10 \times 10^{5}$ scans were accumulated using a pulse delay of $300 \mathrm{~ms}$. Prior to Fourier transformation, a line broadening of 0 to $75 \mathrm{~Hz}$ was applied, depending on the sensitivity of the sample. Relative carbon distribution was determined by integration of signal intensity in the various chemical shift regions, given in Table 1, via an integration routine supplied with the instrument software. Depending on the signal to noise ratio, mean coefficients of variation between 1 and $15 \%$ were recently found for the relative contribution of different carbons species to the total intensity of the solid-state CPMAS ${ }^{13} \mathrm{C}$ NMR spectrum (Knicker, 1993; Knicker et al., 2000).

With the exception of the solid-state CPMAS ${ }^{15} \mathrm{~N}$ NMR spectra of the Mangrove Lake peat, all ${ }^{15} \mathrm{~N}$ NMR spectra were obtained on a Bruker MSL-300 (30.4 MHz) with a spinning speed of $4.5 \mathrm{kHz}$. For the Mangrove Lake samples a Chemagnetics CMC-300 (30.2 MHz) spectrometer was used at a spinning speed of $3.5 \mathrm{kHz}$. Contact times between 0.7 and $1 \mathrm{~ms}$ and pulse delays between 100 and $300 \mathrm{~ms}$ were applied. For the used samples at natural ${ }^{15} \mathrm{~N}$ abundance, between $2 \times 10^{5}$ and $2 \times 10^{6}$ scans were necessary. A line broadening of 100 and $200 \mathrm{~Hz}$ was used. The chemical shift is referenced to the nitromethane scale $(=0 \mathrm{ppm})$ and was adjusted with ${ }^{15} \mathrm{~N}$ enriched glycine $(-347.6 \mathrm{ppm})$.

\section{RESULTS}

\section{Organic Carbon and Nitrogen Composition in Peats}

The CPMAS ${ }^{13} \mathrm{C}$ NMR spectra of an upper (80 to 100 $\mathrm{cm})$ and a deeper layer $(100$ to $200 \mathrm{~cm}$ ) of a sapric peat from Torreblanca, Spain are shown in Fig. 1. Their relative intensity distribution is given in Table 1 . Compared with CPMAS ${ }^{13} \mathrm{C}$ NMR spectra of undegraded vascular plant material (Knicker et al., 1996a,b), the

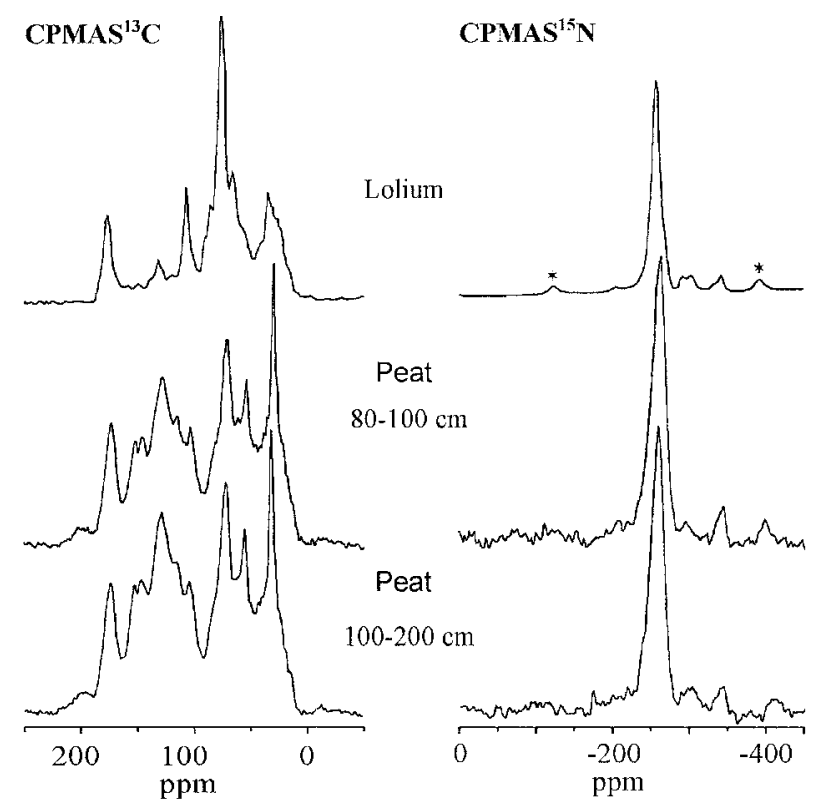

Fig. 1. Cross polarization magic angle spinning (CPMAS) ${ }^{13} \mathrm{C}$ and ${ }^{15} \mathrm{~N}$ nuclear magnetic resonance (NMR) spectra of two layers of the Torreblanca (Spain) peat in comparison with those obtained from fresh ryegrass (Lolium perenne L.) material (Knicker et al., 1996b). Asterisks indicate spinning side bands. relative intensity of the aromatic $\mathrm{C}$ region (160 to 110 ppm) increases while that of the O-alkyl-C region (110 to $60 \mathrm{ppm})$ decreases. This and the sharp signals at 153 and $148 \mathrm{ppm}$, typical for O-substituted carbons of guaiacyl and syringyl units in lignin, indicate a preferential loss of carbohydrates, such as cellulose and hemicellulose, relative to lignin. This is in accordance with other studies, in which peatified stem wood of Scotch heather [Calluna vulgaris (L.) Hull]) (van der Heijden and Boon, 1994) and various other peatified vascular plant remains at different stages of peatification (Bates et al., 1991; Dudley et al., 1990) were analyzed, demonstrating that in peats, anaerobic decomposition of plant material is selective.

A relatively high signal intensity is observed in the region between 45 and $0 \mathrm{ppm}$. The low alkyl-C (45 to $0 \mathrm{ppm}$ ) to carboxyl and amide C (220 to $160 \mathrm{ppm}$ ) ratios of 1.9 for the upper and 1.5 for the lower layer indicate that short chain alkyl acids dominate over long alkyl chains. The high content of alkyl-C was also seen in other studies (Dudley et al., 1990) and was explained with contributions of fungal and microbial remains and their metabolic products. The identification of sterols of algal origin in some Spanish peats and lignites (del Río et al., 1992) indicates that algal residues may also have an effect on the organic composition of peats. Interestingly, aliphatic biopolymers are also observed in vitrinite from coals (Zhang et al., 1993). The latter was suggested to be the result of migration and deposition of humic material into cell lumina of the decaying wood.

The CPMAS ${ }^{15} \mathrm{~N}$ NMR spectra of the Torreblanca peats (Fig. 1) (Knicker et al., 1996b) and the peat from Padul are dominated by a signal around $-260 \mathrm{ppm}$, assignable to amides, and show a small signal for amino groups in amino acids ( $-346 \mathrm{ppm}$ ) (Witanowski et al., 1993), which indicates the presence of peptide-like structures. Those compounds may derive from residual plant components or fungal and microbial remains that have been physically or chemically protected against further microbial degradation. Those signals assigned to peptide-like structures are also identified in the solid-state ${ }^{15} \mathrm{~N}$ NMR spectrum of material derived from a peat

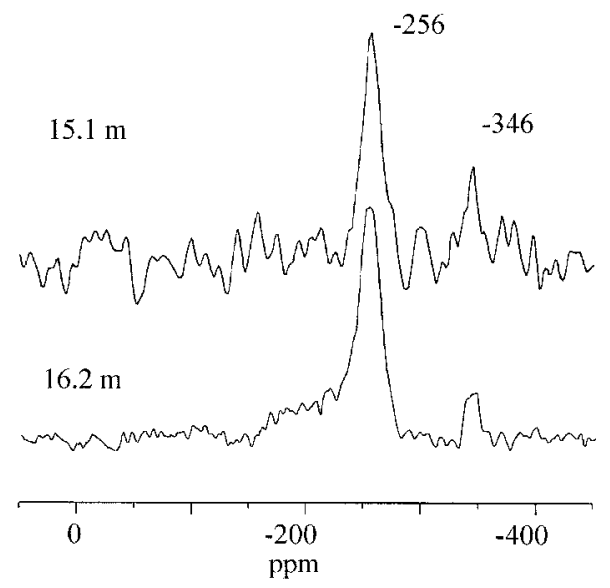

Fig. 2. Cross polarization magic angle spinning (CPMAS) ${ }^{15} \mathrm{~N}$ nuclear magnetic resonance (NMR) spectra of the peat from Mangrove Lake, Bermuda. 
layer $(15.1 \mathrm{~m})$ underlying a freshwater sapropel from the Holocene Mangrove Lake, Bermuda (Fig. 2). For a deeper, and thus older layer of the Mangrove Lake peat at $16.2 \mathrm{~m}$, some alteration in nitrogen composition can be detected from the CPMAS ${ }^{15} \mathrm{~N}$ NMR spectrum. A broad shoulder at the downfield side of the main signal at $-258 \mathrm{ppm}$ in the chemical shift region of pyrrole-N ( -150 to $-240 \mathrm{ppm})$ is observed. Thus, we have the first evidence for the emergence of heteroaromatic-N.

\section{Organic Carbon and Nitrogen Composition in Coals}

During prolonged peatification, the lignin macromolecular structure is preserved but a gradual decrease in the syringyl to guaiacyl ratio (van der Heijden and Boon, 1994) and a relative increase in coumaryl structural units (Orem et al., 1996) was observed. This trend suggests a decrease of methoxyl carbons by demethylation. These units are transformed to hydroxyls and increased condensation (Hatcher, 1988) occurs. The loss of methoxyl units in the early stages of lignite formation is also indicated by the solid-state ${ }^{13} \mathrm{C}$ NMR spectra of the deposits from the Miocene Granada Basin (Fig. 3). Compared with the Padul peat, the ratio between the intensity in the region between 140 and $110 \mathrm{ppm}$ (C-substituted or protonated aryl-C) to that in the region between 160 and $140 \mathrm{ppm}$ (O-aryl-C) increases from 2.6 to 3.7 and 3.9 in the lignite samples obtained at depths of 1.5 and $3.5 \mathrm{~m}$, respectively (Table 1 ).

Concomitantly, a relative increase in the alkyl region from $27 \%$ in the Padul peat to $46 \%$ in the upper lignite layer from the Arenas del Rey deposit can be detected.

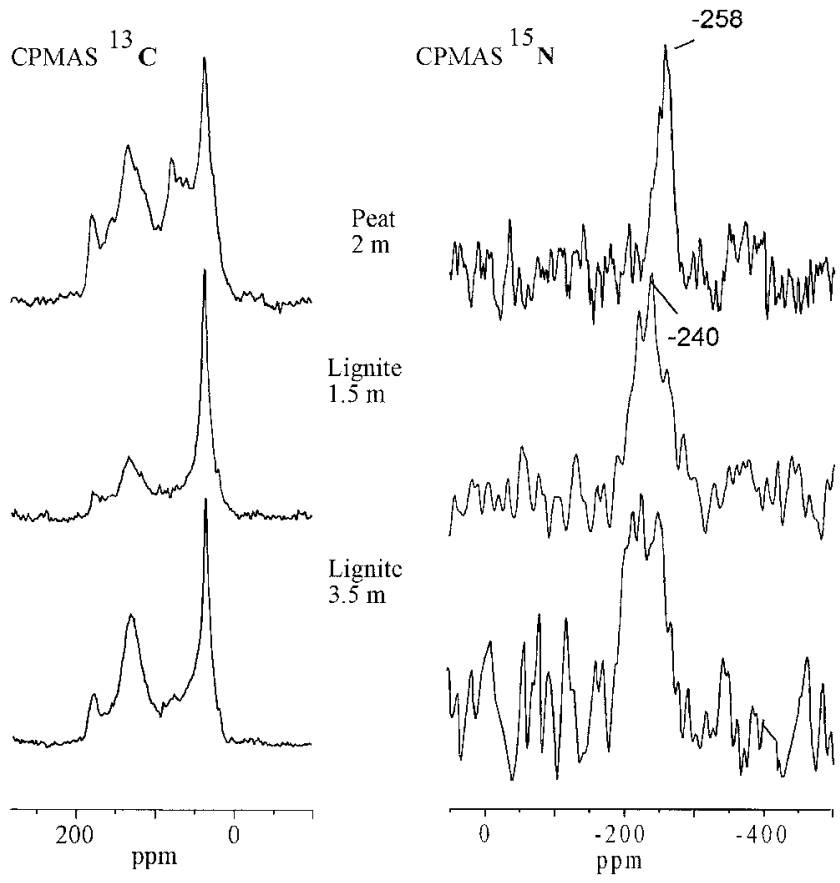

Fig. 3. Cross polarization magic angle spinning (CPMAS) ${ }^{13} \mathrm{C}$ and ${ }^{15} \mathrm{~N}$ nuclear magnetic resonance (NMR) spectra of the peat from the Padul Turba deposit and the lignite from the Arenas del Rey deposit.
With increasing depths of the deposit, an increase in aromaticity from 23 to $34 \%$ (160 to $110 \mathrm{ppm}$ ) is observed. However, due to the broadness of the aromatic signal at $128 \mathrm{ppm}$, and the fact that there is little signal intensity in the $\mathrm{O}$-alkyl region, the intensity between 110 and $100 \mathrm{ppm}$ should be included if the aromaticity of the samples is elucidated. Then, values of 28 and $39 \%$, respectively, are determined.

This increase in aromaticity continues with maturation as depicted in the CPMAS ${ }^{13} \mathrm{C}$ NMR spectra of the highly volatile A bituminous coal PSOC 1362 derived from the Freeport Formation (Lawrence County, Pennsylvania, USA) (Glick and Davis, 1991) and the coalified gymnosperm wood of the anthracite rank (Lockatong Formation, Pennsylvania, USA) (Hatcher, 1988). This increase in aromaticity with increasing rank from lignite to anthracite was previously taken as an indication that dealkylation of alkyl side chains in aromatic rings proceeds with possible replacement of hydrogen (Hatcher, 1988)

As indicated by the broad signal around $-240 \mathrm{ppm}$ in the CPMAS ${ }^{15} \mathrm{~N}$ NMR spectra of the coals, pyrroletype- $\mathrm{N}$ represents the major nitrogen fraction of such samples. In contrast to the spectra of the matured peats, an amide signal cannot be separated from the broad peak around $-240 \mathrm{ppm}$. It seems likely that most of the transformation of the nitrogen from amides to heteroaromatic-N occurs during a very small temporal window, namely between late peatification and the lignite stage, and thus at an early stage of coalification. With increasing rank, the dominance of pyrrole-N remains.

It is generally believed that nitrogen in coal occurs not only in pyrroles, but also in pyridine analogs. Neat pyridine shows a resonance line at $-62 \mathrm{ppm}$ while aqueous pyridine gives a signal at $-84 \mathrm{ppm}$ (Witanowski et al., 1993). In the present CPMAS ${ }^{15} \mathrm{~N}$ NMR spectra of coals, only that of the anthracite coalified wood shows a weak signal in this region. Protonation or $\mathrm{N}$ alkylation of pyridine-N leads to a dramatic increase of the magnetic shielding of up to $100 \mathrm{ppm}$ or more (Witanowski et al., 1993). Resonance lines originating from such pyridinium compounds may contribute to the shoulders in the region between -100 and $-200 \mathrm{ppm}$. Another reason why unsubstituted pyridine- $\mathrm{N}$ has no major contribution to the total signal intensity of the solid-state CPMAS ${ }^{15} \mathrm{~N}$ NMR spectra may be because a contact time $t=1 \mathrm{~ms}$ was used. This time was found to be in the range that is optimal for obtaining quantifiable solidstate CPMAS ${ }^{15} \mathrm{~N}$ NMR spectra of decomposed plant material and soil organic matter where low condensation is expected (Knicker et al., 1996b). In coal, on the other hand, heteroaromatic-N can occur within a core of condensed aromatic structures with no protons in proximity. Thus, maximal cross polarization from protons to the nitrogen may occur at a longer $t$. However, as it was recently shown, this is not the case for the coal PSOC 1362 (Knicker et al., 1995), indicating that for this sample too short a $t$ is not an explanation for missing pyridine signals. A longer $t=2.5 \mathrm{~ms}$ only resulted in a signal intensity loss for nitrogen compounds suspected to have strong dipolar interactions. In contrast, in the 


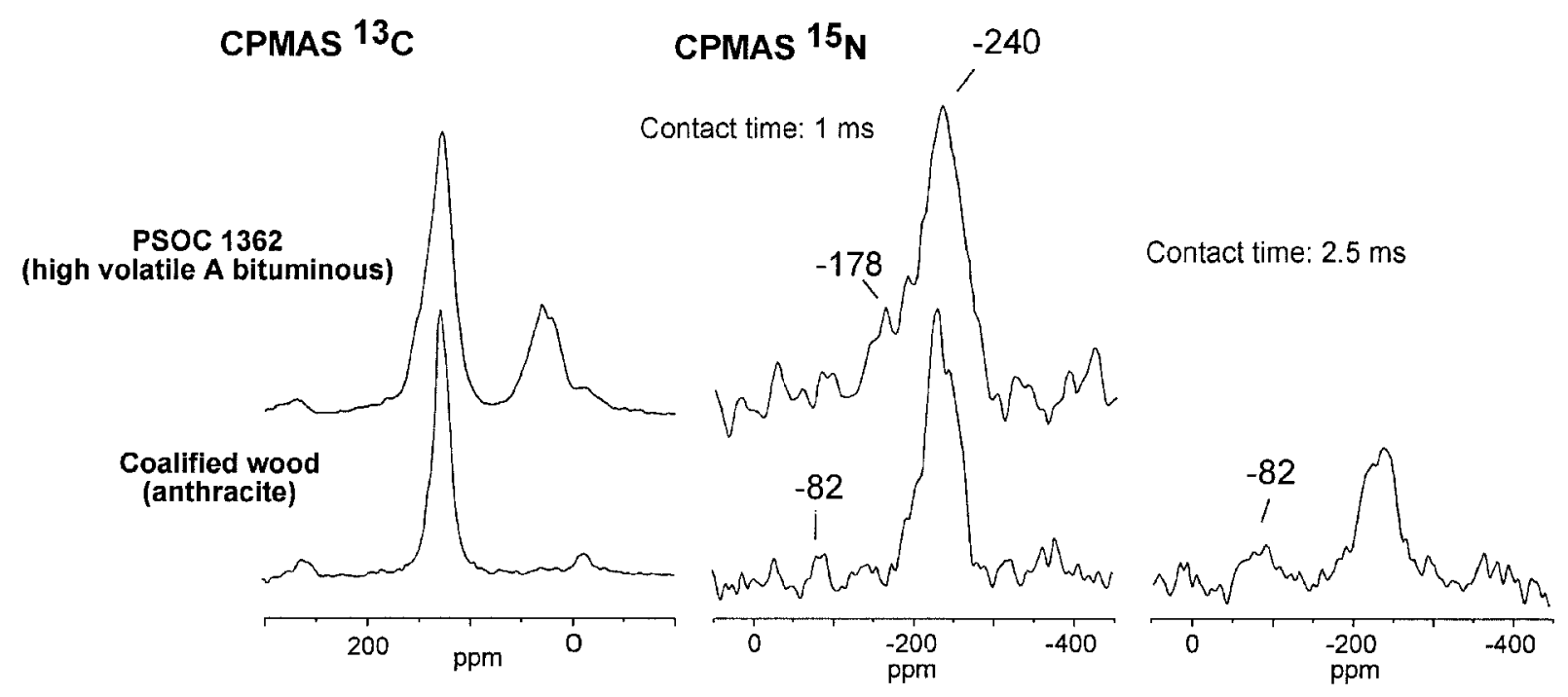

Fig. 4. Cross polarization magic angle spinning (CPMAS) ${ }^{13} \mathrm{C}$ and CPMAS ${ }^{15} \mathrm{~N}$ nuclear magnetic resonance (NMR) spectra of two coals.

solid-state ${ }^{15} \mathrm{~N}$ NMR spectrum of the anthracite wood that was obtained with $t=2.5 \mathrm{~ms}$ (Fig. 4), the signal at -82 becomes more pronounced compared with that in the corresponding CPMAS ${ }^{15} \mathrm{~N}$ NMR spectra acquired with a $t=1 \mathrm{~ms}$. While the signal at $-240 \mathrm{ppm}$ decreases with increasing $t$, no intensity loss can be observed for the signal at $-178 \mathrm{ppm}$. However, one still has to consider that pyridine- $\mathrm{N}$ in coals located at the center of highly condensed structures is depleted of neighboring protons and may therefore not be efficiently polarized during the NMR experiment. Such compounds may not be detectable with a CPMAS ${ }^{15} \mathrm{~N}$ NMR experiment. Accordingly, the signal intensity in the region of pyridine- $\mathrm{N}$ between -40 and $-90 \mathrm{ppm}$ results tentatively from pyridine- $\mathrm{N}$ structures located at the edge or surface of the graphite layers.

\section{Implications for Nitrogen Immobilization in Vascular-Plant-Derived Deposits}

Summarizing the results presented here, some implications for the protection and preservation mechanisms of labile material in organic-matter-rich deposits derived from vascular plants and buried under highly anaerobic conditions are provided. Indications for the formation of heteroaromatic-N compounds during early diagenesis, which could support common models of humification via depolymerization-recondensation reactions, are not found for the Torreblanca peat and the upper peat layer of the sediments from Mangrove Lake. In contrast, peptide-like material seems to dominate the organic nitrogen fraction.

At the deepest peat layer from Mangrove Lake, higher intensity in the chemical shift region of pyrroletype- $\mathrm{N}$ is detected in the solid-state ${ }^{15} \mathrm{~N}$ NMR spectrum. Here, we have the first evidence for the occurrence of heteroaromatic-N, which may be explained by selective enrichment of refractory indole- and pyrrole-containing biopolymers. This pathway is supported by the fact that some porphyrins from chlorophyll or pigments can be found in aged sediments and are widely used as bio- markers in the examination of those sediments (Tissot and Welte, 1984). However, if this explanation is valid, the relative enrichment of those substances should already be detectable in the upper layer of the peat. The sudden alteration in nitrogen functionality, however, suggests that changes in chemical and physical conditions during advanced sediment maturation may be responsible for this shift in nitrogen composition. A changed environment may have favored abiotic conditions and thus the formation of condensed melanoidins or assisted in cyclization of preserved peptide-like material. As coalification continued, heteroaromatic-N becomes the dominating form of organic nitrogen both in kerogens and coals (Knicker et al., 1995, 1996c; Patience et al., 1992). These results give a first indication that late peatification may be an important stage for the formation of heteroaromatic-N. Further research, however, must be performed to obtain more insights into the chemical and physical circumstances that may be responsible for peptide-like material that has survived through the early stages of peatification to become transformed into heteroaromatic- $\mathrm{N}$ at the early stages of coalification.

\section{ACKNOWLEDGMENTS}

The Microanalysis Laboratory of the Universität Regensburg, Germany, is gratefully acknowledged for the elemental analysis of the samples. The authors thank Prof. Dr. G. Almendros (CSIC, Madrid, Spain) for the donation of the Torreblanca peat samples. Prof. Dr. H.-D. Lüdemann (Universität Regensburg, Germany) and Prof. Dr. A.J. Benesi (Pennsylvania State University, Pennsylvania, USA) are gratefully acknowledged for providing the NMR facilities.

\section{REFERENCES}

Almendros, G., A. Polo, and E. Dorado. 1981. Características de la materia orgánica en las formaciones turbosas litorales de Torreblanca (Castellón). Anal. Edafol. Agrobiol. 40:223-225.

Anderson, H.A., W. Bick, A. Hepburn, and M. Stewart. 1989. Nitrogen in humic substances. p. 223-253. In M.B.H. Hayes, P. MacCarthy, R.L. Malcolm, and R.L. Swift (ed.) Humic substances II. John Wiley \& Sons, Chichester, UK. 
Bates, A.L., P.G. Hatcher, H.E. Lerch III, C.B. Cecil, S.G. Neuzil, and Supardi. 1991. Studies of a peatified angiosperm log cross section from Indonesia by nuclear magnetic resonance spectroscopy and analytical pyrolysis. Org. Geochem. 17:37-45.

Del Río, J.C., F.J. González-Vila, and F. Martín. 1992. Variation in the content and distribution of biomarkers in two closely situated peat and lignite deposits. Org. Geochem. 18:67-78.

Derenne, S., H. Knicker, C. Largeau, and P. Hatcher. 1997. Timing and mechanisms of changes in nitrogen functionality during biomass fossilization. p. 243-253. In B.A. Stankiewicz and F.P. van Bergen (ed.) Nitrogen-containing macromolecules in the bio- and geosphere. ACS Symp. Ser. 707. Am. Chem. Soc., Washington, DC.

Dudley, R.L., C.A. Fyfe, and C.M. Preston. 1990. A ${ }^{13}$ C-CPMAS NMR spectroscopic study of the transformation of plant material to peat and coal. Can. J. Spectrosc. 35:31-35.

Florschütz, F., J. Menéndez-Amor, and T.A. Wijmstra. 1971. Palynology of a thick Quaternary succession in southern Spain. Palaeogeogr. Palaeoclimatol. Palaeoecol. 10:233-384.

Glick, D.C., and A. Davis. 1991. Operation and composition of the Penn State coal sample bank and data base. Org. Geochem. 17:421430.

Hatcher, P.G. 1978. The organic geochemistry of Mangrove Lake, Bermuda. NOAA Professional Paper 10. U.S. Dep. of Commerce, Washington, DC

Hatcher, P.G. 1988. Dipolar-dephasing ${ }^{13} \mathrm{C}$ NMR studies of decomposed wood and coalified xylem tissue: Evidence for chemica structural changes associated with defunctionalization of lignin structural units during coalification. Energy \& Fuels 2:40-58.

Hatcher, P.G., and L.A. Ronankiw. 1985. Nuclear magnetic resonance studies of organic-matter-rich sedimentary rocks of some early mesozoic basins of the eastern United States. p. 65-69. In G.R.J. Robinson and A.L. Froelich (ed.) Second U.S. Geological Survey workshop on the Early Mesozoic Basin of the eastern United States. U.S. Gov. Print. Office, Washington, DC.

Hatcher, P.G., B.R.T. Simoneit, F.T. Mackenzie, A.C. Neumann, D.C Thorstenson, and S.M. Gerchakov. 1982. Organic geochemistry and pore water chemistry of sediments from Mangrove Lake, Bermuda. Org. Geochem. 4:93-112.

Ikan, R. 1996. The Maillard reaction. Consequences for the chemical and life sciences. John Wiley \& Sons, Chichester, UK.

Kelly, K.R., and F.J. Stevenson. 1996. Organic forms of N in soil. p. 407-427 In A. Piccolo (ed.) Humic substances in terrestrial ecosystems. Elsevier Science, Amsterdam.

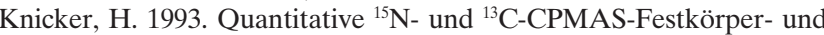
${ }^{15} \mathrm{~N}$ Flüssigkeits-NMR-Spektroskopie an Pflanzenkomposten und natürlichen Böden. Ph.D. thesis. Universität Regensburg, Germany.

Knicker, H., G. Almendros, F.J. González-Vila, F. Martín, and H.-D. Lüdemann. 1996a. ${ }^{13} \mathrm{C}$ - and ${ }^{15} \mathrm{~N}$-NMR spectroscopic examination of the transformation of organic nitrogen in plant biomass during thermal treatment. Soil Biol. Biochem. 28:1053-1060.

Knicker, H., J.C. del Río, P.G. Hatcher, and R.D. Minard. 2001 Identification of protein remnants in insoluble geopolymers using TMAH thermochemolysis/GC-MS. Org. Geochem. 32:397-409.

Knicker, H., R. Fründ, and H.-D. Lüdemann. 1993. The chemical nature of nitrogen in soil organic matter. Naturwissenschaften 80 : 219-221.

Knicker, H., and P.G. Hatcher. 1997. Survival of protein in an organic- rich sediment-Possible protection by encapsulation in organic matter. Naturwissenschaften 84:231-234.

Knicker, H., P.G. Hatcher, and A.W. Scaroni. 1995. Solid-state ${ }^{15} \mathrm{~N}$ NMR spectroscopy of coal. Energy \& Fuels 9:999-1002.

Knicker, H., P.G. Hatcher, and A.W. Scaroni. 1996b. A solid-state ${ }^{15} \mathrm{~N}$ NMR spectroscopic investigation of the origin of nitrogen structures in coal. Int. J. Coal Geol. 32:255-278.

Knicker, H., and H.-D. Lüdemann. 1995. N-15 and C-13 CPMAS and solution HR NMR studies on the chemical modification of N-15 enriched plant material during 600 days of microbial degradation. Org. Geochem. 23:329-341.

Knicker, H., S. Saggar, R. Bäumler, P.D. McIntosh, and I. KögelKnabner. 2000. Soil organic matter transformation in tussock grassland of New Zealand by Hieracium pilosella L. Biol. Fertil. Soils 32:194-201.

Knicker, H., A.W. Scaroni, and P.G. Hatcher. $1996 \mathrm{c} .{ }^{13} \mathrm{C}$ and ${ }^{15} \mathrm{~N}$ NMR spectroscopic investigation on the formation of fossil algal residues. Org. Geochem. 24:661-669.

Knicker, H., M.W.I. Schmidt, and I. Kögel-Knabner. 1999. Nature of organic nitrogen in fine particle size separates of sandy soils of highly industrialized areas as revealed by NMR spectroscopy. Soil Biol. Biochem. 32:241-252.

Martín, A., and L. Garcia-Rosell. 1970. Relación U/Th en sedimentos carbonosos. I. Cuenca de Arenas del Rey (Granada). Bo. R. Soc. Esp. Hist. Nat. Secc. Geol. 68:57-64.

Orem, W.H., S.G. Neuzil, H.E. Lerch, and C.B. Cecil. 1996. Experimental early-early stage coalification of a peat sample and a peatified wood sample from Indonesia. Org. Geochem. 24:111-125.

Patience, R.L., M. Baxby, K.D. Bartle, D.L. Perry, A.G.W. Rees, and S.J. Rowland. 1992. The functionality of organic nitrogen in some recent sediments from the Peru upwelling region. Org. Geochem. 18:161-169

Pines, A., G.G. Gibby, and J.S. Waugh. 1973. Proton-enhanced NMR of dilute spins in solids. J. Chem. Phys. 59:569-590.

Schaefer, J., and E.O. Stejskal. 1976. Carbon-13 nuclear magnetic resonance of polymers spinning at magic angle. J. Am. Chem. Soc. 98:1031-1032.

Schnitzer, M. 1985. Nature of nitrogen of humic substances from soil. p. 303-325. In G.R. Aiken, D.M. McKnight, R.L. Wershaw, and P. MacCarthy (ed.) Humic substances in soil, sediment and water. John Wiley \& Sons, New York.

Schulten, H.-R., C. Sorge, and M. Schnitzer. 1995. Structural studies on soil nitrogen by Curie-point pyrolysis-gas chromatography/mass spectrometry with nitrogen-selective detection. Biol. Fertil. Soils 20:174-184

Tissot, B.P., and D.H. Welte. 1984. Petroleum formation and occurrence. Springer-Verlag, Berlin.

Van der Heijden, E., and J.J. Boon. 1994. A combined pyrolysis mass spectrometric and light microscopic study of peatified Calluna wood isolated from raised bog peat deposits. Org. Geochem. 22: 903-919.

Witanowski, M., L. Stefaniak, and G.A. Webb (ed.) 1993. Nitrogen NMR spectroscopy. Annu. Rep. on NMR Spectroscopy 25. Academic Press, London.

Zhang, E., P.G. Hatcher, and A. Davis. 1993. Chemical composition of pseudo-phlobaphinite precursors: Implications for the presence of aliphatic biopolymers in vitrinite coal. Org. Geochem. 20:721734. 